\title{
Media diplomacy in public administration: analysis of the effectiveness of Ukrainian national branding
}

\section{Volodymyr Shypovskyi *}

Received: August 4, 2020 | Revised: August 20, 2020 | Accepted: August 31, 2020

DOI: $10.33445 /$ sds.2020.10.4.11

\begin{abstract}
Since 1991, the Ukrainian authorities have repeatedly changed the vector of the country's development depending on the views and intentions of the ruling politicians, which has led to negative consequences for the development of all spheres of activity of Ukrainians. One of these consequences is a decrease in the country's authority in the world community. Among the threats facing our state on the way to protection of national interests and national security, the most vulnerable link was the information sphere. It should be noted that the issue of coordinated and proper use of communication opportunities at all levels of public policy - public diplomacy, public relations, military relations, information and psychological operations, measures aimed at promoting the goals of the state has always been acute. Public diplomacy is the realization of the soft power of the country in the international arena, the promotion of the interests of the state in the world by mobilizing the support of the foreign community. This support is achieved by stimulating the desire of the foreign community to consume the ideals of democracy, good governance, integrity, prosperity, security, success and unlimited opportunities for human development. Public diplomacy is one of the components of strategic communications, which has a key task - the formation of the image of the state and its institutions at the international level, the consolidation of important brands in the global information space. The development of state branding should be based primarily on the formation of the state/institutional narrative and broadcast to different target audiences. Thus, public diplomacy involves the formation of the image of all institutional components of the state. The success of economic growth and the dynamic development of relations with other countries largely depends on how the country's brand is formed and promoted in the domestic and global markets. Creating a positive image of the country should be the subject of special attention of the Government and any composition of the Supreme Rada of Ukraine. The most effective tool of public diplomacy is the media and social networks, which, as mass media, should work to promote national ideas among the population of the country and outside Ukraine.
\end{abstract}

Key words: public administration, national brand, media diplomacy, public diplomacy, strategic communications, national narrative.

\section{Introduction}

The concept of state (national) branding originates from the definition, analysis and scientific understanding of four main conceptual categories, namely - country of origin, branding of territory, public diplomacy and national identity. Country of origin and branding of territories focus on the promotion of certain economic interests (exports, tourism, investment). National branding - the image of the country in the international arena in political, economic, cultural dimensions. Another area of research is relevant to the issue of the international image of the country - the identity of the organization and the reputation of the organization, the issue of communication and direct dependence of the concepts of national identity, brand and image of

\footnotetext{
${ }^{*}$ Corresponding author: The National Defence University of Ukraine named after Ivan Cherniakhovskyi, Senior research officer of Research Section of the Educational and Research Center of Strategic Communications in the Sphere of National Security and Defense, Kyiv, Ukraine, e-mail: vladimir.shipovsky@gmail.com, ORCID: 0000-0003-3743-3064
} 
the country. Because each country has its own unique name, and is perceived differently by people inside and outside the country, a nation or country may have its own brand.

National (state) brand - a general set of features of the nation (country) in the minds of international stakeholders, which has the following elements: people, places (territories), culture and language, history, food, fashion, famous people, global brands and others [1].

The national state brand can be based on key ideas of different orientations: talented people who attach special value to the administrativeterritorial unit; erroneous information that has long been spread by hostile states; exceptional prospects for state development, which can be achieved only by representatives of a particular nation, etc. No matter what idea is chosen, it is important to remember that it is important to purposefully and systematically promote it in the world community. This process requires maximum coherence and consistency. Just one event that falls out of the overall concept of the brand will destroy the holistic image of the country.

The national brand (or state) is determined by the perception of the country on 6 factors: tourist attractiveness, human capital, quality of exported goods, government justice, attractiveness of culture and sports, investment attractiveness and attractiveness of the country as a place of residence. These factors form a hexagon of National brands, which illustrates the main areas of influence on the national brand, as well as explains the process of brand design [2].

The formation of the state brand is as follows:

goals and objectives of state branding are defined;

target audiences and ways to promote the brand are identified;

stereotypes about the country in the target audience are explored;

defines the preferences, expectations and requirements of the target audience, original features and characteristics that, in her opinion, should have a positive brand of the state;

the state brand is being constructed;

a brand promotion strategy and an appropriate action plan are developed, which, in particular, covers the translation of the constructed state brand into real ones;

contexts (visual, verbal, communicative);

control over the implementation of the state branding program;

evaluation of intermediate results;

adjustment, if necessary, of the model and strategy of state branding and monitoring the effectiveness of the existing state brand [3].

\section{Material and methods}

The main objectives of the article are understanding, what a state brand is for Ukraine today, consideration current issues of promoting Ukraine's interests in the international political arena through the media and social networks, assessment the best practices of advanced countries in using effective tools of public diplomacy (for example) and highlight the main directions of meganarratives for public branding Ukraine in the world.

\section{Results and discussion}

The peculiarity of the national brand is that it allows to involve people in the formation of an effective image of the country through their identification with the citizens of this state. Awareness of oneself as a full-fledged participant of the country will contribute not only to the formation of the necessary state image, but also to the development of cooperation in all spheres of public life. The most effective way to increase the country's authority is through public diplomacy, which influences the community through, above all, the media. The US State Department defines the term "public diplomacy" as "government-funded programs aimed at informing or influencing the public opinion of foreign countries through publications, films, 
cultural exchanges, radio and television." In a broader sense, public diplomacy in the United States finds its expression primarily in interpersonal contacts in educational programs, scientific and cultural exchanges, as well as in open political dialogue. [4]

By definition, public diplomacy is a special form of foreign policy. Consider the definition of the term public diplomacy on the components: diplomacy and publicity. The word "diplomacy" comes from the ancient Greek "diploma", which denoted the credentials of ambassadors in the form of double plates. In modern political discourse, there are several definitions of "diplomacy":

- type of activity to manage relations between countries, the ability to conduct management activities;

- a form of cooperation between states by peaceful means;

- activities of heads of state, government and special bodies of foreign relations to implement the goals and objectives of foreign policy, as well as to protect the rights and interests of the state abroad.

Therefore, diplomacy can be defined as follows - consistent and systematic activities of the state leadership and its authorized state bodies, aimed at implementing the foreign policy of the state peacefully. The word public means public, public, open. As you know, the basis of a legitimate state policy of any state is to consider public opinion, public opinion, through the formation of which you can change the policy of another state. The concept of public diplomacy is based on this. This is its essence as a tool of global governance. According to world scholars, public diplomacy is a way for governments to conduct international relations through open media and through interaction with a wide range of nongovernmental organizations in order to influence the actions and policies of other governments. In general, it should be noted that public and traditional diplomacy are two different instruments of foreign policy aimed at achieving one goal: to exert political influence on the governments of other countries. Public diplomacy is a set of technologies and tools of foreign policy implemented in the framework of political institutions and actors, both state and non-state, aimed at implementing a comprehensive diplomatic strategy of the state through the impact on the population of a foreign state to influence its political processes and political decisions.

With major environmental pressures and calls for conservation, nations are now

adopting preservation agendas for future generations and exploring sustainable development strategies and techniques. Nations, as destinations for tourism and foreign direct investment, are dependent on natural and cultural/heritage resources to form their attraction bases that are linked to the economic vitality of local communities. Therefore, the sustainable development of a nation brand, when properly managed, will provide the economic incentive to attract investors, tourists and generate income for local communities. For nation brands to remain competitive, it is essential to understand the key determinants of market competitiveness. This article provides a framework for the analysis of sustainable market competitiveness factors of the nation brand [5].

To understand the regulatory framework of diplomacy through the media - media diplomacy in Ukraine, it is necessary to consider the main points of the legal framework of Ukraine concerning the information policy of Ukraine. First, let's consider some aspects of the Doctrine of Information Security of Ukraine. The Doctrine of Information Security of Ukraine (hereinafter - the Doctrine) determines the national interests of Ukraine in the information sphere, threats to their implementation, directions and priorities of state policy in the information sphere.

The purpose of the Doctrine is to clarify the principles of formation and implementation of state information policy, primarily to counter the destructive information influence of the Russian Federation in the context of its hybrid war.

The Doctrine defines the national interests of Ukraine in the field of information, the main in the field of public diplomacy are the following interests:

vital interests of the person:

ensuring constitutional human rights and 
freedoms to collect, store, use and disseminate information;

ensuring the constitutional human rights to the protection of privacy;

protection from destructive information and psychological influences;

\section{vital interests of society and the state:}

protection of Ukrainian society from the aggressive influence of destructive propaganda, primarily by the Russian Federation;

ensuring the free circulation of information, except as provided by law;

development and protection of national information infrastructure;

preservation and increase of spiritual, cultural and moral values of the Ukrainian people;

ensuring the comprehensive development and functioning of the Ukrainian language in all spheres of public life throughout Ukraine;

free development, use and protection of national minority languages and promotion of the study of international languages;

strengthening information ties with the Ukrainian diaspora, promoting the preservation of its ethnocultural identity;

formation of an effective legal system to protect the individual, society and the state from destructive propaganda influences;

creation of a system and mechanisms of protection against negative external information and psychological influences, first of all propaganda, considering the norms of international law;

safe functioning and development of the national information space and its integration into the European and world information space;

development of the system of strategic communications of Ukraine;

formation of a positive image of Ukraine in the world, communication of operative, reliable and objective information about events in Ukraine to the international community;

development of Ukraine's foreign broadcasting system and ensuring the availability of a foreignlanguage Ukrainian channel in cable networks and satellite broadcasting outside Ukraine.

Actual threats to the national interests and national security of Ukraine in the information sphere are: conducting by the aggressor state of special information operations in other states in order to create a negative image of Ukraine in the world;

information expansion of the aggressor state and its controlled structures, in particular by expanding its own information infrastructure on the territory of Ukraine and in other states;

information domination of the aggressor state in the temporarily occupied territories;

inefficiency of the state information policy, imperfection of the legislation concerning regulation of public relations in the information sphere, uncertainty of a strategic narrative, insufficient level of media culture of a society.

The priorities of state policy in the information sphere should be:

\section{on information security:}

improving the powers of state regulatory bodies operating in the information space of the state, in order to achieve an adequate level of state capacity to meet real and potential threats to the national interests of Ukraine in the information sphere;

identification of mechanisms for regulating the work of telecommunications enterprises, printing companies, publishing houses, television and radio organizations, television and radio centers and other enterprises, institutions, organizations, cultural institutions and the media, as well as the use of local radio stations, television centers and printing houses for military purposes and outreach among troops and the population; bans on the operation of receiving and transmitting radio stations for personal and collective use and the transmission of information via computer networks in the conditions of introduction of the legal regime of martial law;

optimization of legislative mechanisms for the implementation of Ukraine's obligations under the European Convention on Trans frontier Television in relation to states that are not signatories to this Convention;

ensuring full coverage of the territory of Ukraine by digital broadcasting, primarily in border areas, as well as temporarily occupied territories;

building an effective and efficient system of strategic communications;

combating misinformation and destructive 
propaganda by the Russian Federation;

preventing the use of the state's information space for destructive purposes or for actions aimed at discrediting Ukraine at the international level;

on ensuring the protection and development of the information space of Ukraine, as well as the constitutional right of citizens to information:

ensuring the functioning of Public Television and Radio Broadcasting of Ukraine, including its proper financing;

creation of a broadcasting system of territorial communities, which will help expand communication opportunities and reduce conflicts within communities;

formation of a system of state support for the production of domestic audiovisual product;

promotion, including through audiovisual means, in particular social advertising, of the main stages and experience of state formation, values of freedom, democracy, patriotism, national unity, protection of Ukraine from external and internal threats; on the formation of a positive international image of Ukraine:

thorough reform of the system of presenting information about Ukraine in the international arena;

development of public diplomacy, including cultural and digital;

intensification of coordinated information work of foreign diplomatic missions of Ukraine;

promoting the spread and development of Ukraine's foreign broadcasting system;

creation and functioning of the legal mechanism of interaction of state bodies with civil society institutions for the purpose of informational support of commercial, humanitarian, educational, cultural and other activities of such institutions outside Ukraine;

constant monitoring of the aggressor state's propaganda, development and operative implementation of adequate countermeasures;

preventing the use of the international information space for destructive purposes or for actions aimed at discrediting Ukraine at the international level;

reforming the system of relations with the Ukrainian diaspora by ensuring closer cooperation and carrying out effective measures, in particular in the framework of human-to-human communications;

participation in international cultural events in order to present national culture and identity;

introduction of international cultural festivals

in Ukraine in order to promote Ukrainian culture and develop human-to-human communications [6].

As we can see, the Doctrine of Information Security of Ukraine focuses not only on information security measures, but also regulates some cultural features of actions in the information space, both internally (state) and externally (world).

The next document that reveals and regulates the use of public diplomacy tools is the Concept of popularization of Ukraine in the world and promotion of Ukraine's interests in the world information space, which specifies the tasks and ways to implement them, namely:

Formation of an effective mechanism for popularizing Ukraine in the world:

submission to the Government of a draft normative legal act on the establishment of a permanent Interdepartmental Commission on the Promotion of Ukraine in the World under the Cabinet of Ministers of Ukraine with the involvement of experts, representatives of civil society;

monitoring, content analysis and compilation of sociological data on the perception of Ukraine in the world depending on the regions and population groups;

approval of strategies for popularization of educational, investment, health, scientific potential of Ukraine in accordance with the competence of central executive bodies.

Ensuring institutional cooperation with civil society institutions, representatives of people's diplomacy:

establishing effective institutional cooperation with civil society institutions;

involvement in the development of program documents, in particular institutional promotion strategies, in specific areas of experts, representatives of civil society;

monitoring the implementation of program documents, in particular institutional promotion strategies, in specific areas with the involvement 
of experts, representatives of civil society.

Creation of a single standard for the elements of Ukraine's promotion in the world:

formation of a technical task with the participation of experts, representatives of civil society;

holding a competition to create a single standard for the elements of Ukraine's promotion in the world, public discussions and coordination with expert groups;

monitoring and analyzing information on reforms in Ukraine for further communication for countries and audiences for which these topics are relevant [7].

The next Law, which concerns the requirements for information content, creates the legal basis for the organization and defines the tasks and functions of state foreign broadcasting of Ukraine, the principles of state foreign broadcasting to protect Ukraine's national interests abroad, forming and maintaining a positive image of Ukraine in the world. objective information about events in Ukraine, official domestic and foreign policy and the position of the state, the activities of public authorities and local governments is the "Law of Ukraine on the foreign broadcasting system of Ukraine". Part № 6 of this law defines the main tasks of the state foreign broadcasting of Ukraine, namely:

objective, complete, timely and impartial, comprehensive and balanced information on socially significant events in Ukraine, official domestic and foreign policy and the position of the state, the activities of public authorities and local governments;

providing a platform for discussions on the official position of public authorities and local governments on important issues of politics, culture, sports, education, science and economy, exchange of ideas between different cultures and peoples of the world;

ensuring balanced and transparent access of subjects of socio-political, cultural and economic life to programs (programs) of discussion format, in particular in the form of debates;

providing sufficient, comprehensive information support for the process of Ukraine's integration into the European Union and EuroAtlantic collective security structures; popularization of Ukrainian culture, promotion of languages and cultures of national minorities;

promoting the information, cultural and educational needs of foreign audiences, including through the creation and dissemination of economic, historical and documentary, cultural and artistic, educational, entertainment, sports programs, programs for children and youth, people with disabilities, other social groups;

promoting the strengthening of Ukraine's international prestige and increasing investment attractiveness [8].

Part №9 of the "Law of Ukraine on Television and Radio Broadcasting" defines the requirements for the protection of the interests of the state and national television and radio production:

in the total broadcasting volume of each television and radio organization at least 50 percent should be a national audiovisual product or musical works of Ukrainian authors or performers;

the broadcaster has no right to distribute audiovisual works in which the criminal nature of the communist totalitarian regime of 1917-1991 in Ukraine is denied or justified;

when conducting competitions for the issuance of broadcasting licenses, the National Council is guided by the need to ensure the information needs of citizens, protect the interests of the state, national broadcasters, the development of the national television and radio base. Based on these priorities, the National Council determines on a competitive basis the relevant requirements for the program concept of broadcasting.

These documents related to media diplomacy at the legislative level protect and promote the dissemination of information about the cultural features of Ukraine, promoting the country's image and supporting national branding.

In the final part of my article I want to mention the experience of a country that successfully uses the features of national branding, namely - the features of the US experience. America sits in first place on the Nation Brand Index for 2010 as the world's most valuable country brand. Many attributes this to President Obama's election in 2009. Simon Anholt, the creator of the Nation Brands Index and one of the top experts in the concept and theory of nation branding stated 
while, last year, a significant leap in its standing to the top nation spurred by the election of President Obama, the reputation landscape of the countries comprising the top 20 have remained relatively stable, however, the uncertain global economic climate, combined with financial bailouts, natural disasters and civil unrests have created some interesting shifts, especially among southern European nations". (Nation Branding) The index takes perceptions of people around the world for a country's, cultural, political, commercial and human assets, investment potential and tourist appeal of each nation". Anholt also works with the assumption, that nation branding can be divided into six primary subfields: tourism, exports, governance, people, culture and heritage, and investment and immigration" (Diaspora Matters). This brings us to the ever-interesting dichotomy of America sitting on top of the 'most valuable country brand' throne and yet encounters ever more anti-American sentiment worldwide. Many people and nations may condemn foreign policy actions, foreign intervention, aggressive free trade politics and dismissive attitude towards environmental protection, but at the same time buy Apple computers, drink Coke and lust after the newest Nike's. So, does a 'poor image' really affect the commercial brand of a country? After walking through the office asking co-workers what they thought of America, I was answered with words such as Obama, California, Dollars, Capitalism, Globalization and even Empire; however, I also saw a large number of Apple products on desks and in ears and coke bottles from lunch. Negative feelings created by US actions and policy has not seemed to make a difference in the sale and spread of US products. If nation branding is a combination of factors, then a downward shift in one factor (foreign policy public opinion) may be directly correlated with a downward shift in another (market goods). This is particularly Interesting in the case of the USA. It seems to sit on either end of the spectrum on the various factors. The US comes in second on the World Tourism Rankings put out by the UN World Tourism Organization, and come in 4th in world exports according to the CIA World Factbook. Yet every day we are faced with news stories proclaiming the negative public opinion of the US, anti-American sentiment growing and Americans doing nothing to counteract this trend. So, are we the best or the worst, loved or hated? Are we more well known for Apple or for Abu Ghraib? Perhaps we are neither and our 'national brand' is a little more complicated than that [9].

Effectiveness of events for increasing of national brand can be measured. Futurebrand publishes the Country Brand Index every year, which includes an overall ranking of the 75 countries and rankings by dimension, FutureBrand collected quantitative and qualitative data from Approximately 2,500 opinion-formers and frequent international business or leisure travelers in 17 countries (USA, Canada, Brazil, Argentina, Mexico, UK, Germany, France, Russia, Turkey, South Africa, UAE, India, China, Thailand, Japan and Australia). complete perception dashboards for the top five country brands, regional leaders, and 'ones to watch' for the future. Futurebrand tests a global research sample based on the Hierarchical Decision Model (HDM) which involves determining an individual's awareness, familiarity, association, and preference towards a country's brand. In their 2018-19 ranking, the top 5 nations brands were (ranked from first to fifth) Germany, Switzerland, Japan, Sweden, and Canada [10].

\section{Conclusions}

So today the media has become not only an integral part of foreign policy, but also an effective tool for influencing the consciousness of mankind. Media diplomacy is the involvement of the media in resolving conflicts and creating public support for an international agreement. Considering the system of media diplomacy of Ukraine, it should be acknowledged that it has not yet been formed. The main problem is the low popularity of domestic media abroad and the lack of stability in the state narrative. If we consider the development of media diplomacy in Ukraine, it should be noted that, having its own powerful media resource at the international level, it is necessary to learn to skillfully use foreign media and actively involve social networks in media diplomacy. At the current stage of development of the media and 
their growing influence on diplomacy, it is worth noting the steady trend of social media, which intercept the palm of supremacy in the role of media diplomacy for their greater ease of use, as well as the tendency to "soft power" problems due to pressure by non-military means.

\section{References}

1. Fan Y. (2010) Branding the Nation: Towards A Better Understanding. Place Branding and Public Diplomacy. Vol. 6, 2. URL: https://www.academia.edu/5185202/Brandi ng_the_nation_towards_a_better_understa nding

2. Anholt S. Branding Places and Nations / Clifton, R., Simmons, J. \& Ahmad S. (eds), Brands and Branding, Princeton, NJ: Bloomberg Press, London

3. Shtelmashenko A. (2013) State brand: essence and features of formation. Scientific Bulletin of the Academy of Municipal Administration. Series: Management. vol.2. URL: http://nbuv.gov.ua/UJRN/Nvamu_ upravl_2013_2_43_[In Ukrainian]

4. U.S. Department of State, Dictionary of International Relations Terms, Washington, D.C., 1987

5. Salah Hassan, Abeer A. Mahrous. Nation branding: the strategicimperative for sustainablemarket competitiveness. Journal of Humanities and Applied Social Sciences Emerald Publishing Limited 2632-279X DOI 10.1108/JHASS-08-20190025, URL: www.emeraldinsight.com/2632-279X.htm

6. Decision of the National Security and Defense
Council of Ukraine of December 29, 2016 “On the Doctrine of Information Security of Ukraine" approved by the Decree of the President of Ukraine of February 25, 2017 № 47/201. URL: https://zakon.rada.gov.ua/ laws/show/47/2017\#Text_[In Ukrainian]

7. Order of the Cabinet of Ministers of Ukraine of June 7, 2017 № 383-r Kyiv “On approval of the action plan for the implementation of the Concept of popularization of Ukraine in the world and promotion of Ukraine's interests in the world information invironment". URL: https://zakon.rada.gov.ua/laws/show/3832017-\%D1\%80\#Text [In Ukrainian]

8. Law of Ukraine "On the system of foreign broadcasting of Ukraine". URL: https://zakon.rada.gov.ua/laws/show/85619\#Text [In Ukrainian]

9. Jessica Bell. Nation Branding: Country Specific Evaluation - URL: http://www.cultural diplomacy.org/culturaldiplomacynews/conte nt/pdf/Cultural_Diplomacy_Outlook_Report _2011_-_04-01.pdf

10. The Future Brand Index 2020. URL: http://www.culturaldiplomacy.org/culturaldi plomacynews/content/pdf/Cultural_Diplom acy_Outlook_Report_2011_-_04-01.pdf 